\title{
KONRAD ŁUCZAK
}

Uniwersytet Kardynała Stefana Wyszyńskiego

\section{ZASADA SKUTECZNOŚCI JAKO PODSTAWA OBOWIĄZKU UWZGLĘDNIENIA PRZEZ NSA Z URZĘDU PRAWA UE}

\section{UWAGI WSTĘPNE}

Trybunał Sprawiedliwości Unii Europejskiej (dalej: Trybunał lub TSUE) nakłada na sądy państw członkowskich poprzez swoje wyroki rozmaite obowiązki o charakterze zarówno pozytywnym, jak i negatywnym ${ }^{1}$. Zaliczają się do nich m.in.: wykładnia prawa krajowego w zgodzie z prawem UE, wprowadzanie nowych środków prawnych, uwzględnianie $z$ urzędu prawa UE czy odmowa zastosowania krajowego przepisu prawnego niezgodnego z prawem $\mathrm{UE}^{2}$. Wymienione obowiązki spełnieniają funkcję instrumentalną, bowiem służą efektywnemu i jednolitemu stosowaniu prawa UE oraz efektywnej ochronie unijnych uprawnień jednostek ${ }^{3}$. Trybunał przekształcając w ten sposób krajowe systemy

\footnotetext{
1 P. Van Cleynenbreugel, Judge-Made Standards of National Procedure in Post-Lisbon Constitutional Framework, «European Law Review»1/2012, s. 92-93.

2 J. Temple Lang, The Principle of Loyal Cooperation and the Role of the National Judge in Community, Union and EEA Law, «ERA Forum» 7/2006, s. 476-477.

A. WróBeL, Sądy administracyjne jako sq̨dy Unii Europejskiej, «Zeszyty Naukowe Sądownictwa Administracyjnego» 2010/5-6, s. 474-475. Orzecznictwo TSUE określa zatem, w jaki sposób sądy krajowe powinny stosować i kontrolować przestrzeganie
} 
prawne, skoncentrował się na działalności sądów, gdyż stanowią one główne ośrodki, w których odbywa się proces urzeczywistniania prawa $\mathrm{UE}^{4}$ (nie umniejszając w tym zakresie pozycji administracji publicznej i prawodawcy). „Odkrywane” w orzeczeniach Trybunału obowiązki sądów krajowych mają być lekarstwem stosowanym w konkretnych sprawach na niedostatecznie przychylne dla prawa UE regulacje krajowe, w tym na braki legislacyjne ${ }^{5}$.

Niniejszy artykuł poświęcono jednemu z takich obowiązków. Polega on na konieczności uwzględnienia przez sąd z urzędu prawa UE, niezależnie od treści krajowych rozwiązań procesowych, które w sposób wyraźny lub ukryty sprzeciwiają się temu. Aktualizacja in concreto wskazanego obowiązku następuje pod pewnymi warunkami, które wynikają z zasad skuteczności i równoważności, współtworzących zasadę procedur krajowych. Zakłada ona, że: „wobec braku szczegółowych regulacji na poziomie unijnym prawo unijne, a w szczególności roszczenia jednostek wywodzone $\mathrm{z}$ tego systemu są wykonywane przez krajowe instytucje sądowe i administracyjne oraz na podstawie krajowych przepisów prawnych, głównie o charakterze proceduralnym"6. Wracając do zasady skuteczności przewiduje ona, że działanie krajowych przepisów procesowych nie może powodować, aby realizacja unijnego uprawnienia stała się praktycznie niemożliwa, a nawet nadmiernie utrudniona ${ }^{7}$, z kolei w myśl zasady równoważności, krajowe normy procesowe mające

prawa UE, Z. KMIEciak, Postępowanie administracyjne i sądowoadministracyjne a prawo europejskie, Warszawa 2010, s. 20.

4 W. Postulski, Jednolite i efektywne stosowanie prawa wspólnotowego przed sądami państw członkowskich, «Przegląd Sądowy» 6/2002, s. 31.

5 S. MајкошsкA, Rola sędziów w procesie integrowania prawa wspólnotowego zwewnętrznym porządkiem prawnym, [w:] Wymiar sprawiedliwości w Unii Europejskiej, red. C. Mik, Toruń 2001, s. 190-191.

Wyrok TSUE z 27 lutego 2014 r. w sprawie Pohotovost's. r. o. przeciwko Miroslavowi Vašucie, C-470/12, pkt 46, «Legalis» nr 787149; N. Pó£тorak, Efektywność prawa Unii Europejskiej a polska procedura administracyjna i sądowoadministracyjna, "Zeszyty Naukowe Sądownictwa Administracyjnego» 3/2014, s. 38.

Wyrok TSUE z 18 kwietnia 2013 r. w sprawie Mariana Irimie przeciwko Administraţia Finanţelor Publice Sibiu, Administraţia Fondului pentru Mediu, C-565/11, pkt 23, «Legalis» nr 640647. 
za zadanie realizować unijne uprawnienie jednostki nie mogą być mniej korzystne niż krajowe normy procesowe dotyczące realizacji podobnego uprawnienia o charakterze krajowym ${ }^{8}$.

Dalsze rozważania odnoszą się do zasady skuteczności. Zmierzają one do ustalenia, czy dla NSA rozpoznającego sprawę w granicach wyznaczonych podstawami skargi kasacyjnej może powstać obowiązek uwzględnienia $z$ urzędu prawa UE. Postawione pytanie sprowadzam zatem do analizy konstrukcji podstaw skargi kasacyjnej pod kątem zasady skuteczności. Pełna ocena instytucji skargi kasacyjnej, czyli obejmująca każdy współtworzący ją przepis prawny, przeprowadzona w świetle zarówno zasady skuteczności, jak i zasady równoważności wykracza poza ramy jednego artykułu, stąd konieczne było objęcie nią tylko niektórych zagadnień. Analiza rozpoczyna się od scharakteryzowania konstrukcji podstaw kasacyjnych, następnie przechodzi do omówienia zasady skuteczności, by zakończyć się oceną pod kątem tej zasady trzech wybranych sytuacji, odnoszących się do opracowania zarzutu naruszenia materialnego przepisu prawa UE w ramach podstawy kasacyjnej. Chodzi o: 1) zupełny brak podstawy kasacyjnej; 2) niewskazanie w niej przepisu prawa, którego naruszenie się zarzuca i 3) zakaz skonstruowania podstawy kasacyjnej niezgodnej z wiążącą wykładnią NSA, o którym mowa w art. 190 zd. drugie ustawy z 30 sierpnia 2002 r. Prawo o postępowaniu przed sądami administracyjnymi ${ }^{9}$ (p.p.s.a.).

\section{KONSTRUKCJA PODSTAW KASACYJNYCH I ICH MOC WIĄŻĄCA}

Główna rola podstaw kasacyjnych polega na wyznaczeniu zarówno zakresu, jak i intensywności weryfikacji zaskarżonego orzeczenia wojewódzkiego sądu administracyjnego ${ }^{10}$ (dalej: WSA). Dzięki prawidłowemu sformułowaniu podstawy kasacyjnej dotyczącej naruszenia

\footnotetext{
8 Wyrok TSUE z 26 stycznia 2010 r. w sprawie Transportes Urbanos y Servicios Generales SAL przeciwko Administración del Estado. C-118/08, pkt 31, «Legalis» nr 187263.

9 Tekst jedn. Dz.U. z 2016 r., poz. 718, ze zm.

10 G. RzĄsa, Podstawy skargi kasacyjnej w postępowaniu sądowoadministracyjnym, «PiP» 66.8/2008, s. 58.
} 
prawa UE, dla NSA powstaje obowiązek jej merytorycznej oceny (skutek pozytywny). Natomiast określone rodzaje braków czy uchybień w tym zakresie powodują, że NSA, co do zasady, nie ma ani obowiązku, ani nawet możliwości zbadania zgodności z prawem UE zaskarżonego orzeczenia WSA (skutek negatywny).

Wskazane konsekwencje prawidłowej, jak i błędnej konstrukcji podstaw kasacyjnych mają swoje źródło w zasadzie związania NSA granicami skargi kasacyjnej, wyrażonej w art. $183 \$ 1$ p.p.s.a. ab initio, który stanowi, że NSA rozpoznaje sprawę w granicach skargi kasacyjnej, bierze jednak z urzędu pod rozwagę nieważność postępowania. Oprócz tego, że zasada ta nakłada obowiązek rozpoznania sprawy: „w ramach wyznaczonych wszystkimi zarzutami, przytoczonymi w powołanych podstawach kasacyjnych"11, to jednocześnie zakazuje badania, czy zaskarżone orzeczenie WSA narusza inne przepisy prawa niż te, określone w podstawach kasacyjnych ${ }^{12}$. NSA nie może zatem sam poszukiwać, konkretyzować czy uzupełniać naruszeń prawa, gdy nie ujęto ich w podstawach kasacyjnych ${ }^{13}$, bowiem: „treść skargi kasacyjnej sama w sobie musi być wystarczająca do zbadania legalności zaskarżonego orzeczenia"14. Problem uwzględnienia przez NSA z urzędu prawa UE pojawia się zatem tylko w przypadku skutku negatywnego, a to dlatego, że w skardze kasacyjnej albo w ogóle nie sformułowano zarzutu naruszenia prawa UE, bądź też uczyniono to, lecz w sposób wadliwy.

Dla opracowania poprawnej podstawy kasacyjnej, prowadzącej do wywołania pozytywnego skutku, nie wystarczy literalne odczytanie przepisów p.p.s.a. Przewidują one jedynie, że należy przytoczyć podstawy kasacyjne, ich uzasadnienie (art. $176 \$ 1$ pkt 2 p.p.s.a.) oraz wyróżniają ich dwa rodzaje: 1) naruszenie prawa materialnego przez błędną

11 Uchwała NSA z 26 października 2009 r., I OPS 10/09, «ONSAiWSA» 1/2010, poz.1.

12 B. Dauter, Metodyka pracy sędziego sądu administracyjnego, Warszawa 2012, s. 541 .

13 M. WiĄCEK, Skarga kasacyjna do Naczelnego Sądu Administracyjnego (w świetle orzecznictwa), «PiP»69.3/2011, s. 53; wyroki NSA z 28 stycznia 2014 r., II OSK 2029/12, «Legalis» nr 909549; z 6 sierpnia 2015 r., II GSK 2229/14, «Legalis» nr 1331603.

14 Wyrok NSA z 12 marca 2013 r., II GSK 2468/11, «Legalis» nr 793933. 
jego wykładnię lub niewłaściwe zastosowanie i 2) naruszenie przepisów postępowania, jeżeli uchybienie to mogło mieć istotny wpływ na wynik sprawy (art. 174 p.p.s.a.). Niezbędne jest zatem skorzystanie również z poglądów ukształtowanych w judykaturze oraz w doktrynie. Odnosząc to do prawa unijnego można stwierdzić, że prawidłowa podstawa kasacyjna dotycząca naruszenia prawa UE powinna w sposób jasny i precyzyjny wskazywać ${ }^{15}$ :

a) czy zarzuca się naruszenie unijnego przepisu materialnego, procesowego, czy też obu przepisów łącznie,

b) odpowiednią podstawę kasacyjną z art. 174 p.p.s.a.,

c) przepis prawa UE, który naruszył WSA z powołaniem dokładnej jednostki redakcyjnej tekstu aktu normatywnego,

d) na czym polegało naruszenie przepisu prawa UE poprzez jego błędną wykładnię lub niewłaściwe zastosowanie (obie formy naruszenia odnoszą się zarówno do prawa materialnego, jak i procesowego) ${ }^{16}$,

e) argumenty na poparcie sformułowanych zarzutów naruszenia przepisu prawa UE, tj. krytykę przyjętego przez WSA stanowiska co do wykładni lub sposobu zastosowania przepisu prawa UE,

f) trafną zdaniem skarżącego wykładnię lub sposób zastosowania przepisu prawa UE wraz z argumentacją,

g) stwierdzenie, że naruszenie unijnego przepisu procesowego mogło mieć istotny wpływ na wynik sprawy i wykazanie, jaki byłby inny wynik sprawy gdyby nie doszło do tego naruszenia,

h) związek pomiędzy niewłaściwym zastosowaniem materialnego przepisu prawa a ustaleniami stanu faktycznego sprawy ${ }^{17}$.

15 B. Gruszczyński, [w:] Prawo o postępowaniu przed sądami administracyjnymi. Komentarz, B. Dauter, B. Gruszczyński, A. Kabat, M. NiezgódKa-Medek, Warszawa 2011, s. 524-525; W. PiĄtek, Podstawy skargi kasacyjnej w postępowaniu sadowoadministracyjnym, Warszawa 2011, s. 284-295 i 381-382; wyroki NSA z: 12 września 2013 r., II GSK 814/12, «Legalis» nr 738487; 14 lipca 2015 r., II FSK 1473/13, «Legalis» nr 1332105; 22 lipca 2015 r., II FSK 1572/13, «Legalis» nr 1332250.

16 B. Dauter, op. cit., s. 541; wyrok NSA z 10 stycznia 2013 r., I OSK 2029/11, «Legalis» $\mathrm{nr} 758329$.

17 Wyroki NSA z 31 stycznia 2012 r., I OSK 1171/12, «Legalis» nr 759904. W doktrynie trafnie przy tym zauważono, że nawet w razie prawidłowego ustalenia stanu 
Nie każde uchybienie w sformułowaniu podstawy kasacyjnej dotyczącej naruszenia prawa UE powoduje wystąpienie skutku negatywnego. Do tego rodzaju nieistotnych błędów zalicza się przede wszystkim: a) omyłki o charakterze oczywistym, b) określenie materialnego przepisu prawa UE przepisem procesowym i na odwrót, c) wskazanie przepisu prawa UE dopiero w uzasadnieniu skargi kasacyjnej ${ }^{18} \mathrm{czy}$ d) niepowołanie się na art. 174 p.p.s.a. ${ }^{19}$ Wady tego rodzaju nie pociągają za sobą potrzeby uzupełnienia czy konkretyzowania podstawy kasacyjnej przez NSA, jak również nie stoją na przeszkodzie w zakreśleniu granic rozpoznania sprawy oraz przeprowadzeniu pod jej kątem merytorycznej weryfikacji orzeczenia WSA. Obok tego występują różne przypadki braków lub uchybień w budowie podstawy kasacyjnej, w rezultacie których w grę wchodzi skutek negatywny. Przykładowo chodzi o brak wskazania przepisu prawa UE lub określenia na czym polegało jego naruszenie $^{20}$, czy też o niepodanie jakichkolwiek argumentów za podniesionym naruszeniem ${ }^{21}$.

W tym punkcie można zatem przejść do określenia, na czym polega uwzględnienie przez NSA z urzędu prawa UE w kontekście podstaw kasacyjnych oraz zasady związania granicami skargi kasacyjnej ${ }^{22}$.

faktycznego WSA mógł dopuścić się niewłaściwego zastosowania prawa materialnego poprzez nieprawidłową wypowiedź dotyczącą ustalenia konsekwencji prawnych, R. Hauser, W. Piątek, A. Skoczylas, [w:] System prawa administracyjnego, I: Sądowa kontrola administracji, red. R. Hauser, Z. Niewiadomski, A. Wróbel, Warszawa 2014, s. 442-443.

18 J.P. TARno, Ewolucja orzecznictwa Naczelnego Sądu Administracyjnego w zakresie podstaw skargi kasacyjnej i zażalenia, «Zeszyty Naukowe Sądownictwa Administracyjnego» 5-6/2010, s. 431.

19 Wyrok NSA z 27 marca 2014 r., II GSK 44/13, «Legalis» nr 951956.

20 B. Gruszczý́ski, op. cit., s. 522-523; wyrok NSA z 16 stycznia 2014 r., I FSK 231/13, «Legalis» nr 909716.

${ }^{21}$ Wyrok NSA z 3 czerwca 2014 r., II FSK 1521/12, «ONSAiWSA» 3/2015, poz.61.

22 Jedną kwestię stanowi sposób uwzględnienia prawa UE $\mathrm{z}$ urzędu przez sąd, na czym się koncentruję, a inną cele, jakie się dzięki temu osiąga, co jedynie w tym miejscu odnotuję. W grę wchodzi zwłaszcza: ocena normy krajowej z punktu widzenia prawa UE, bezpośrednie zastosowanie normy unijnej, merytoryczna analiza zarzutów podniesionych przez strony, weryfikacja rozstrzygnięcia sądu niższej instancji czy podniesienie i rozważenie zarzutów skierowanych wobec stanu faktycznego lub prawnego 
Dochodzi tu do zaistnienia rozbudowanego skutku pozytywnego, a także do przełamania skutku negatywnego. Po pierwsze, mamy więc do czynienia z rozbudowanym skutkiem pozytywnym, bowiem NSA nie tylko samodzielnie tworzy prawidłową podstawę kasacyjną wraz z jej uzasadnieniem albo uzupełnia wadliwą podstawę kasacyjną, ale również ma obowiązek merytorycznie ją rozpoznać. Urzeczywistnienie tego skutku znajdzie wyraz dopiero w samym uzasadnieniu orzeczenia NSA kończącym sprawę, stąd - technicznie rzecz ujmując - podstawa kasacyjna nie zostanie sformułowana $\mathrm{w}$ dokładnie taki sam sposób, w jaki czyni to strona w skardze kasacyjnej, lecz jako typowa wypowiedź sądu o (nie)zasadności podstawy kasacyjnej. Obejmie ona zatem stwierdzenia co do tego, czy konkretny przepis prawa UE został naruszony, czy też nie, w jaki dokładnie sposób, określenie prawidłowej wykładni lub zastosowania tego przepisu (przy stwierdzeniu naruszenia) i przytoczenie argumentów przemawiających za danym stanowiskiem sądu. Po drugie, $w$ konsekwencji zaistnienia rozbudowanego skutku pozytywnego, zostaje przełamany skutek negatywny. NSA samodzielnie formułując, "naprawiając" i rozpoznając podstawę kasacyjną, odstępuje tym samym od zasady związania granicami skargi kasacyjnej.

Przedstawiony sposób uwzględnienia przez NSA z urzędu prawa UE sam przez się nie wyznacza jeszcze przypadków, w których obowiązek ten powstaje, ani nie stanowi argumentu na jego rzecz. Wskazany obowiązek nie ma także charakteru zasady, lecz traktowany jest - nawet przez sam TSUE - jako szczególny przypadek ${ }^{23}$ i dlatego sytuacje, w których się aktualizuje potrzebują szczególnego uzasadnienia opartego na zasadzie skuteczności ${ }^{24}$.

sprawy, N. Pó£тoraк, Ochrona uprawnień wynikających z prawa Unii Europejskiej w postępowaniach krajowych, Warszawa 2010, s. 327.

23 M. BARAn, Stosowanie z urzędu prawa Unii Europejskiej przez sądy krajowe, Warszawa 2014, s. 169 i 213; wyroki TSUE z 14 grudnia 1995 r. w sprawach połączonych Jeroen van Schijndel i Johannes Nicolaas Cornelis van Veen przeciwko Stichting Pensioenfonds voor Fysiotherapeuten, C-430/93 i C-431/93, pkt 22, «Legalis» nr 76850; z 17 grudnia 2009 r. w sprawie Eva Martín Martín przeciwko EDP Editores SL, C-227/08, pkt 19, «Legalis» nr 181055.

24 K. Lenaerts, The Rule of Law and the Coherence of the Judicial System of the European Union, «Common Market Law Review» 6/2007, s. 1647. 


\section{ZASADA SKUTECZNOŚCI JAKO ŹRÓDŁO OBOWIĄZKU DZIAŁANIA SĄDU Z URZĘDU}

W myśl zasady skuteczności, stosowanie krajowych przepisów procesowych nie może doprowadzić do tego, że realizacja unijnych uprawnień jednostki stanie się praktycznie niemożliwa lub nadmiernie utrudniona. Zwięzła choć mglista formuła zasady skuteczności została przekształcona przez TSUE w odniesieniu do reguł procesowych, określających zakres rozpoznania sprawy przez sąd. Trybunał wyprowadził z niej dwie osobne podstawy ${ }^{25}$, które aktualizują obowiązek uwzględnienia przez sąd z urzędu prawa UE.

Pierwsza zakłada, że jeżeli strona nie miała rzeczywistej możliwości powołania się na prawo UE w postępowaniu sądowym, to taką przeszkodę należy usunąć poprzez uwzględnienie przez sąd z urzędu przepisów prawa UE (doktryna van der Weerd) ${ }^{26}$. Została ona następnie przekształcona przez Trybunał w ten sposób, że wyłączono obowiązek uwzględnienia $z$ urzędu prawa UE wtedy, gdy strona pozostała „w całości absolutnie bierna” w postępowaniu sądowym, np. nie wniosła środka prawnego od niekorzystnego dla niej wyroku sądu ani nie powołała się na prawo UE w żadnym postępowaniu sądowym, chociaż miała zapewnioną ku temu rzeczywistą możliwość (doktryna Asturcom) ${ }^{27}$. Doktryny

25 Zgadzam się z poglądem, że podstawa do uwzględnienia przez sąd z urzędu przepisów prawa UE, jaką jest ich przynależność do dziedziny unijnego porządku publicznego, łączy się z zasadą równoważności, a nie z zasadą skuteczności, K. LEnaerts, I. Maselis, K. Gutman, EU Procedural Law, Oxford University Press 2015, s. 135; N. PóŁtorak, Ochrona..., s. 342. Pomijam w dalszych uwagach wyrok TSUE z 14 grudnia 1995 r., w sprawie Peterbroeck, Van Campenhout \& Cie SCS przeciwko Belgian State, C-312/93, «Legalis» nr 76849, z racji tego, że ma on charakter jednostkowy, ściśle związany z okolicznościami jednego, konkretnego przypadku.

${ }_{26}$ Wyrok TSUE z 7 czerwca 2007 r. w sprawach połączonych J. van der Weerd i inni, H. de Rooy sr. oraz H. de Rooy jr., Maatschap H. en J. van 't Oever i in., przeciwko Minister van Landbouw, Natuur en Voedselkwaliteit, C-222/05 do C-225/05, pkt 41, «Legalis» nr 82745; M. Eliantolio, Europeanisation of Administrative Justice?, Groningen 2009, s. 140 .

27 Wyrok TSUE z 6 października 2009 r. w sprawie Asturcom Telecomunicaciones SL przeciwko Cristinie Rodríguez Nogueirze, C-40/08, pkt 47-48, «Legalis» nr 172874. 
van der Weerd nie należy jednak traktować jako ostatniego słowa Trybunału w kwestii obowiązku uwzględnienia przez sąd z urzędu prawa UE, gdyż najpewniej będzie ona rozwijana w kolejnych wyrokach ${ }^{28}$, czego dobrym przykładem jest właśnie doktryna Asturcom.

Druga podstawa wiąże się z ochroną konsumenta. Sąd, uwzględniając z urzędu przepisy prawa UE, zmierzające do udzielenia konsumentowi ochrony przed nieuczciwymi warunkami umownymi, jakimi posługuje się przedsiębiorca, ma wyrównać w ten sposób słabszą pozycję konsumenta oraz jego niedostateczną wiedzę o własnej sytuacji prawnej i regułach rządzących postępowaniami sądowymi ${ }^{29}$. Z racji tego, że sądy administracyjne nie rozpoznają sporów cywilnoprawnych pomiędzy konsumentami a przedsiębiorcami, lecz spory jednostek $\mathrm{z}$ administracją publiczną, dalsze rozważania skupiają się na pierwszej podstawie obowiązku uwzględnienia przez sąd z urzędu prawa UE, tj. na doktrynach van der Weerd i Asturcom.

Obie doktryny złagodziły do pewnego stopnia niejasną treść zasady skuteczności. Usunięto kryterium nadmiernego utrudnienia w realizacji unijnych uprawnień, negatywne ujęcie praktycznej niemożliwości zastąpiono pozytywną formułą rzeczywistej możliwości, a dodatkowo wprowadzono kryterium zachowania strony - na ile była aktywna, a na ile bierna pod względem ochrony swych praw w postępowaniu sądowym. Bez zmian pozostało z kolei to, że doktryny van der Weerd i Asturcom odziedziczyły podstawową wadę zasady skuteczności - Trybunał nie przedstawił ich precyzyjnej, jednoznacznej i wyczerpującej koncepcji, dlatego też przyszłe rozstrzygnięcia Trybunału dotyczące uwzględnienia przez sąd z urzędu prawa UE będą prawdopodobnie

Na doktrynę Asturcom Trybunał powołał się następnie w wyroku z 10 września 2014 r. w sprawie Monika Kušionová przeciwko SMART Capital a.s., C-34/13, pkt 56, «Legalis» nr 1162955.

28 R.H. LauwaArs, The Application of European Law by National Courts 'Ex Officio”, «Fordham International Law Journal» 5/2005, s. 1173.

29 Przykładowo wyroki TSUE z 26 października 2006 r. w sprawie Elisa María Mostaza Claro przeciwko Centro Móvil Milenium SL, C-168/05, «Legalis» nr 83981; w sprawie Martín Martín, C-227/08; K. Lenaerts, I. Maselis, K. Gutman, op. cit., s. 134 . 
utrzymywać się w dotychczasowej tendencji, którą cechuje doraźność i nieprzewidywalnośćs ${ }^{30}$.

Ocena w świetle doktryny van der Weerd przepisów procesowych wpływających na zakres rozpoznania sprawy przez sąd opiera się na dwóch głównych założeniach. Zgodnie z pierwszym, regulację procesową należy poddać wykładni systemowej i funkcjonalnej, skupiając się przede wszystkim na miejscu przepisu w całej procedurze, przebiegu procedury oraz na jej cechach szczególnych przed poszczególnymi sądami krajowymi ${ }^{31}$. W ten sposób przygotowany zostaje przepis procesowy, aby następnie przeanalizować go na podstawie kryterium rzeczywistej możliwości. Skorzystanie z wykładni systemowej i funkcjonalnej nie zmierza jednak do opracowania zbioru rozmaitych hipotez interpretacyjnych i tym samym skomplikowania całej analizy, lecz do odkrycia czy wyeksponowania tych cech przepisu, które z jednej strony jasno zobrazują jego praktyczne znaczenie i funkcjonowanie, natomiast z drugiej pozwolą na uporządkowane, spójne, dokładne i merytorycznie prawidłowe zastosowanie doktryny van der Weerd ${ }^{32}$. Drugie założenie, za którym stoi tzw. proceduralna reguła rozsądku, odnosi się do podstawowych zasad krajowego systemu prawnego, jak np. zasady pewności prawa, zasady prawidłowego przebiegu postępowania, zasady prawa

30 М. Вовек, Why there is no principle of "procedural autonomy" of the member states, [w:] The European Court of Justice and the autonomy of the member states, red. H.-W. Micklitz, B. De Witte, Cambridge-Antwerp-Portland 2012, s. 310-312; J. Engström, National Courts' Obligation to Apply Community Law Ex Officio - The Court Showing new Respect for Party Autonomy and National Procedural Autonomy?, «Review of European Administrative Law» 1/2008, s. 74-75 i 87.

31 Wyroki TSUE w sprawach: van Schijndel, C-430/93, pkt 22; Asturcom, C-40/08, pkt 39; K. Lenaerts, I. Maselis, K. Gutman, op. cit., s. 133.

32 Podane założenia korzystania z wykładni systemowej i funkcjonalnej pozwalają zatem uniknąć formalistycznego stosowania prawa, postulującego m.in. redukcjonizm narzędzi interpretacyjnych, jak również postmodernistycznej pułapki o nieskończonej liczbie prawidłowych hipotez interpretacyjnych, M. Matczak, Summa Iniuria. O błędzie formalizmu w stosowaniu prawa, Warszawa 2007, s. 70 i 113. 
do obrony ${ }^{33}$, czy zasady zakazu reformationis in peius ${ }^{34}$. Robienie użytku z proceduralnej reguły rozsądku w kontekście obowiązku uwzględnienia przez sąd z urzędu prawa UE polega na ustaleniu, czy niezgodność przepisu procesowego z warunkiem rzeczywistej możliwości znajduje wystarczająco mocne uzasadnienie w krajowych zasadach prawa ${ }^{35}$. W tym celu należy ustalić kilka kwestii: jaką wagę posiada dana zasada prawa, czy przepis procesowy stanowi proporcjonalny środek do jej realizacji oraz jaki wynik daje wyważenie takiej zasady z potrzebą zapewnienia efektywności konkretnego unijnego uprawnienia jednostki ${ }^{36}$. O ile zatem pierwsze założenie zaczyna odgrywać swoją rolę jeszcze przed zastosowaniem warunku rzeczywistej możliwości, o tyle drugie aktualizuje się dopiero po stwierdzeniu, że warunek ten został naruszony i potwierdza tym samym, że obowiązek uwzględnienia przez sąd z urzędu prawa UE nie ma charakteru bezwzględnego i absolutnego, lecz wyjątkowy ${ }^{37}$.

Biorąc pod uwagę dotychczasowe ustalenia, można sformułować kilka wniosków w odniesieniu do konstrukcji warunku rzeczywistej możliwości, będącej główną osią doktryny van der Weerd. Przede wszystkim nie dotyczy ona tych przepisów procesowych, których wymagania, chociaż sprawiają, że powołanie się przez jednostkę na prawo UE jest skomplikowane, $w$ tym sformalizowane, są realnie do spełnienia.

33 Wyrok TSUE w sprawach: van Schijndel, C-430/93, pkt 22; van der Weerd, C-222/05, pkt 33.

34 Wyrok TSUE z 25 listopada 2008 r., w sprawie Heemskerk BV, Firma Schaap przeciwko Productschap Vee en Vlees, C-455/06, pkt 46, «Legalis» nr 111476.

35 R.H. LauwaArs, op. cit., s. 1163; K. Lenaerts, I. Maselis, K. Gutman, op. cit., s. 133. Konflikt krajowych przepisów procesowych kształtujących zakres rozpoznania sprawy przez sąd z prawem UE rozwiązuje się więc za pomocą proceduralnej reguły rozsądku, nie zaś zasady pierwszeństwa prawa UE, H. Schebesta, Does the National Court Know European Law? A Note on Ex Officio Application after Asturcom, «European Review of Private Law» 4/2010, s. 859.

36 S. Prechal, R. Widdershoven, Redefining the Relationship between „Rewe-effectiveness" and Effective Judicial Protection, "Review of European Administrative Law» 2/2011, s. 43; N. Pó£torak, Ochrona..., s. 357; J. Engström, The Principle of Effective Judicial Protection after Lisbon Treaty, «Review of European Administrative Law» 2/2011, s. 62.

37 K. KowALIK-BAŃCZYK, Uwzględnianie przez sąd z urzędu zarzutów opartych na prawie wspólnotowym, «Europejski Przegląd Sądowy»12/2007, s. 20. 
Dzięki uczynieniu im zadość, zakresem rozpoznania sprawy zostanie bowiem objęty przepis unijny. Wynika to stąd, że warunek rzeczywistej możliwości powołania się na prawo UE został oderwany od warunku nadmiernego utrudnienia, będącego elementem zasady skuteczności. Wymaganie proceduralne uznane za nadmierne utrudnienie w stopniu absurdalnym, rażącym należałoby przy tym traktować jako brak rzeczywistej możliwości, skoro można uczynić mu zadość hipotetycznie bądź tylko w szczególnie wyjątkowych, śladowych przypadkach.

Następnie wypada odnotować, że konsekwencją zaistnienia sytuacji braku rzeczywistej możliwości powołania się na prawo UE jest to, że unijne uprawnienie nie wchodzi w zakres rozpoznania sprawy przez sąd. Z tym że przyczyną prowadzącą do stanu, że strona nie ma rzeczywistej możliwości powołania się na prawo UE, nie może być jej całkowicie bierne zachowanie się (objęte doktryną Asturcom), ale działanie przepisów procesowych, które bezpośrednio lub pośrednio ustanawiają przesłanki bądź zakazy bezwzględnie wyłączające możliwość powołania się przez jednostkę na unijne uprawnienie w postępowaniu sądowym. Pomiędzy działaniem określonego przepisu procesowego a nieobjęciem uprawnienia unijnego zakresem rozpoznania sprawy musi zatem wystąpić związek przyczynowy.

Kończąc, wypada pokrótce skomentować doktrynę Asturcom. Wyłącza ona obowiązek uwzględnienia przez sąd z urzędu prawa UE, gdy na gruncie krajowych regulacji procesowych strona miała zapewnioną rzeczywistą możliwość powołania się na prawo UE w postępowaniu sądowym, lecz z niej nie skorzystała. Potwierdza tym samym, że powstanie wskazanego obowiązku ma charakter wyjątkowy. Wystąpieniu sytuacji braku rzeczywistej możliwości powołania się na prawo UE może też równolegle towarzyszyć okoliczność, że strona w ogóle nie spróbowała włączyć do zakresu rozpoznania sprawy unijnego uprawnienia. Wydaje się, że wówczas dla sądu aktualizuje się obowiązek uwzględnienia z urzędu prawa UE, ponieważ przyczyna naruszenia warunku rzeczywistej możliwości wynikała $\mathrm{z}$ działania przepisów procesowych, a ewentualna aktywność strony nie powstrzymałaby skutku pozostawienia na marginesie jej unijnego uprawnienia w postępowaniu sądowym. Bierna postawa strony nie usprawiedliwia w takim przypadku naruszenia warunku rzeczywistej możliwości. 


\section{ZASADA SKUTECZNOŚCI WOBEC PODSTAW KASACYJNYCH - ANALIZA TRZECH PRZYPADKÓW}

W tym punkcie zostaną rozpatrzone pod kątem doktryn van der Weerd i Asturcom trzy przypadki dotyczące konstrukcji podstaw kasacyjnych, w których przepis prawa UE - w myśl regulacji p.p.s.a. - nie powinien zostać włączony w zakres rozpoznania sprawy przez NSA, a więc gdy zaistniał negatywny skutek zasady związania granicami skargi kasacyjnej. Analiza zmierza do odpowiedzi na pytanie, czy w którymś z tych przypadków może powstać dla NSA obowiązek uwzględnienia $\mathrm{Z}$ urzędu prawa UE.

Pierwszy z nich charakteryzuje się tym, że w ramach wniesionej skargi kasacyjnej strona w ogóle nie sformułowała podstawy kasacyjnej dotyczącej naruszenia przepisu prawa UE w sposób samodzielny, tj. bez ścisłego związku przedmiotowego z przepisem krajowym. Uważam, że w tej sytuacji dla NSA nie powstaje obowiązek uwzględnienia z urzędu prawa UE bowiem strona, chociaż miała zapewnioną rzeczywistą możliwość przedstawienia w skardze kasacyjnej zarzutu naruszenia unijnego uprawnienia, to pozostała bierna w tej kwestii. Za przyjętym stanowiskiem, przemawia kilka argumentów.

Przede wszystkim, powołanie się na unijne uprawnienie może nastąpić w ramach podstawy kasacyjnej dotyczącej naruszenia prawa materialnego przez błędną wykładnię lub niewłaściwe zastosowanie. Błędna wykładnia prawa wyraża się tu w sformułowaniu nieprawidłowej decyzji interpretacyjnej, która nie oddaje rzeczywistej treści unijnego uprawnienia ${ }^{38}$. $Z$ kolei niewłaściwe zastosowanie prawa polega na: 1) zastosowaniu przepisu prawa UE, który nie powinien być w danym stanie faktycznym zastosowany bądź w rzeczywistości nie istnieje, albo na 2) niezastosowaniu w sprawie przepisu unijnego, który powinien

38 Z reguły przyjmuje się, że błędna wykładnia oznacza nieprawidłowe rozumienie treści przepisu prawnego, wyrok NSA z 16 października 2014, II GSK 2046/14, «Lex» nr 1530462; Z. KMIeciak, Podstawy skargi kasacyjnej do Naczelnego Sadu Administracyjnego, «PiP»60.1/2005, s. 18. Szerzej na temat pojęcia błędnej wykładni prawa z teoretycznoprawnej perspektywy zob. A. Bielska-BrodzIAK, Zarzut „błędnej wykładni”, «Ruch Prawniczy Ekonomiczny i Socjologiczny»1/2006, s. 69 i n. 
znaleźć zastosowanie bądź na pominięciu go z powodu stwierdzenia, że nie istnieje ${ }^{39}$. Jeżeli zatem jednostka uważa, że WSA nadał przysługującemu jej unijnemu uprawnieniu błędną treść albo też nie zapewnił jego ochrony, nie urzeczywistnił go poprzez jego niezastosowanie, to może wymienione rodzaje naruszeń przedstawić w podstawie kasacyjnej. Wówczas NSA będzie miał obowiązek merytorycznego rozpoznania takiej podstawy.

Zgodnie $\mathrm{z}$ następnym argumentem, warunki skonstruowania poprawnej podstawy kasacyjnej zostały wyznaczone przepisami prawa i uszczegółowione orzecznictwem sądów administracyjnych. Są one zatem dostępne dla profesjonalnych pełnomocników, upoważnionych do sporządzenia skargi kasacyjnej (przymus adwokacko-radcowski - art. 175 p.p.s.a.), którzy kierując się nimi, mogą opracować skargę kasacyjną na wysokim poziomie merytorycznym, poprzez dokładne i rzetelne określenie, w jaki sposób WSA naruszył prawo UE ${ }^{40}$. Ponadto ostatnie sprawozdanie z działalności sądów administracyjnych z 2015 r. pokazuje wyraźnie, że warunki skonstruowania prawidłowych podstaw kasacyjnych są w rzeczywistości możliwe do spełnienia, skoro NSA corocznie, licząc chociażby od 2012 r., rozpoznaje merytorycznie tysiące skarg kasacyjnych $^{41}$. Skarga kasacyjna jest zatem skutecznym, a nie iluzorycznym środkiem zaskarżenia orzeczeń WSA.

39 Wyroki NSA z 16 października 2014 r., I GSK 376/13, «Lex» nr 1528823; z 17 marca 2010 r., I FSK 203/09, «Legalis» nr 243159; G. RzĄsA, op. cit., s. 62-63. W doktrynie zasygnalizowano, że przy zarzucie niezastosowania przepisu prawa materialnego należy: „wyjaśnić, dlaczego przepis przyjęty za podstawę prawną nie ma związku z ustalonym stanem faktycznym i jaki przepis sąd powinien zastosować”, H. KNYSIAK-MoLCzYK, Skarga i skarga kasacyjna w postępowaniu sądowoadministracyjnym. Komentarz. Orzecznictwo, Warszawa 2014, s. 177.

40 M. KanIA, Zwyczajne środki zaskarżenia w postępowaniu przed sądami administracyjnymi, Warszawa 2009, s. 122-123; K. ŁUKASIK, Konstytucyjne prawo do sądu „każdego" a przymus adwokacko-radcowski w sprawie skargi kasacyjnej w postępowaniu przed Sądem Najwyższym, "Annales Univeristatis Mariae Curie-Skłodowska. Sectio G» 2/2013, s. 169.

41 Informacja o działalności sądów administracyjnych $w 2015$ roku, Naczelny Sąd Administracyjny, Warszawa 2016, s. 339. 
Warto zauważyć, że podstawa kasacyjna skierowana jest w pierwszej kolejności na naruszenie prawa UE, które popełnił WSA. Jednakże w jej ramach można także wskazać na naruszenie przepisu prawa UE, związane z działaniem organu administracji publicznej, które przez WSA zostało zaakceptowane (powtórzone), bądź też którego sąd nie dostrzegł. Podstawa kasacyjna obejmuje w takim razie pierwotne naruszenie prawa UE przez WSA, tj. gdy prawo UE zostało po raz pierwszy naruszone przez sąd w drodze błędnej wykładni lub niewłaściwego zastosowania, jak i naruszenie wtórne, polegające na tym, że WSA nie usunął naruszenia prawa UE wynikającego z działania organu administracji publicznej (zaakceptował je bądź go nie zauważył). Konkludując, podstawa kasacyjna daje jednostce ochronę przed niezgodnym z prawem UE działaniem zarówno WSA, jak i pośrednio organu administracji publicznej $^{42}$.

Przeciwko uwzględnieniu przez NSA z urzędu prawa UE w omawianej sytuacji przemawia także doktryna Asturcom. Przy założeniu, że strona co prawda wniosła skargę kasacyjną, więc nie wykazała się całkowitą biernością, należy jednak wskazać, że nie ujęła ona w niej zarzutu powiązanego z unijnym uprawnieniem. Zaniedbanie miało zatem miejsce i dlatego NSA nie powinien go „rekompensować”, podejmując określone działania $\mathrm{z}$ urzędu.

Na koniec pozostaje argument, w myśl którego regulacje p.p.s.a. dotyczące skargi kasacyjnej generalnie nie zakazują objęcia podstawą kasacyjną naruszenia prawa UE. Wyjątek stanowi tu art. 190 zdanie drugie p.p.s.a., wyłączający oparcie skargi kasacyjnej od orzeczenia WSA wydanego po ponownym rozpoznaniu sprawy, na podstawach sprzecznych z wykładnią prawa ustaloną w tej sprawie przez NSA. Zagadnienie to będzie przedmiotem analizy w dalszej części artykułu.

42 Podkreślił to Trybunał Konstytucyjny m.in. w wyroku z 20 września 2006 r., SK 63/05, «OTK-A» 8/2006, poz. 108 ogólnie wskazując, że NSA sprawuje nadzór judykacyjny nad kontrolą legalności decyzji administracyjnych, którą przeprowadza WSA. Jeszcze dobitniej wyraził tę myśl NSA w uchwale I OPS 10/09: „kontrola orzeczeń WSA jest pewnym wariantem kontroli działalności administracji publicznej, aczkolwiek dokonywanej w sposób pośredni, a nie bezpośredni, tak jak to czyni WSA". 
Drugi przypadek odnosi się do niewskazania w podstawie kasacyjnej przepisu prawa UE, który mógł naruszyć WSA. Warunek precyzyjnego określenia w podstawie kasacyjnej, ewentualnie w jej uzasadnieniu ${ }^{43}$, przepisu prawa UE, ma na celu wyznaczenie pod jakim względem NSA zweryfikuje orzeczenie WSA. Niespełnienie tego warunku wyklucza dopuszczalność zbadania, czy orzeczenie WSA naruszyło konkretny przepis prawa. Niewskazanie przepisu prawa UE zalicza się więc do braków poważnych, nie zaś nieistotnych. Może on co prawda zostać uzupełniony jeszcze $\mathrm{w}$ terminie na wniesienie skargi kasacyjnej ${ }^{44}$, ale musi to uczynić strona z własnej inicjatywy. W myśl art. 177a p.p.s.a. ${ }^{45}$ ani WSA, ani NSA nie wzywa bowiem do jego uzupełnienia w trybie art. $49 \$ 1$ p.p.s.a. ${ }^{46}$ Poza tym, niespełnienie omawianego warunku nie może zostać naprawione poprzez przytoczenie nowego uzasadnienia podstaw kasacyjnych (art. $183 \$ 1$ zdanie drugie p.p.s.a.), ponieważ uregulowanie to służy do przedstawienia dodatkowych argumentów za trafnością danego zarzutu, a nie do skonstruowania nowego zarzutu ${ }^{47}$.

Jeżeli w podstawie kasacyjnej lub przynajmniej w jej uzasadnieniu nie wskazano przepisu prawa UE, to NSA nie może ocenić, czy przepis ten został naruszony przez WSA. Bez znaczenia pozostaje okoliczność, że podstawa kasacyjna dotycząca prawa UE w jakimś stopniu została opracowana, np. ogólnie wspomniano o prawie UE albo nawet określonym akcie prawnym, ponieważ NSA i tak byłby zmuszony do domyślenia się czy wywnioskowania, który konkretnie przepis prawa mógł naruszyć

43 J.P. TARNO, op. cit., s. 431.

44 B. AdAmiak, Skarga i skarga kasacyjna w postępowaniu sądowoadministracyjnym, Komentarz, Warszawa 2014, s. 595; J.P. TARno, Odrzucenie skargi kasacyjnej, «Przegląd Podatkowy» 6/2005, s. 35.

45 Przepis ten stanowi, że: „Jeżeli skarga kasacyjna nie spełnia wymagań przewidzianych w art. 176, innych niż przytoczenie podstaw kasacyjnych i ich uzasadnienie, przewodniczący wzywa stronę do usunięcia braków w terminie siedmiu dni pod rygorem odrzucenia skargi”.

46 Zgodnie z tym przepisem: „Jeżeli pismo strony nie może otrzymać prawidłowego biegu wskutek niezachowania warunków formalnych, przewodniczący wzywa stronę o jego uzupełnienie lub poprawienie w terminie siedmiu dni pod rygorem pozostawienia pisma bez rozpoznania, chyba że ustawa stanowi inaczej".

47 B. Dauter, op. cit., s. 543; B. Gruszczyński, op. cit., s. 566. 
WSA. Tymczasem zasada związania NSA podstawami kasacyjnymi zabrania aktywnego poszukiwania przez sąd, jaki przepis prawa został naruszony i uzupełniania w ten sposób podstawy kasacyjnej.

Warunek precyzyjnego wskazania w środku prawnym przepisu prawa, którego naruszenie zarzuca się sądowi, został oceniony pod względem zgodności z konstytucyjnym prawem do sądu, powiązanym z zasadami sprawiedliwości proceduralnej oraz proporcjonalności w wyroku Trybunału Konstytucyjnego (TK) z 12 lipca 2011 roku $^{48}$. Problem dotyczył normy procesowej wynikającej z art. $424^{8} \$ 1$ i art. $424^{5} \$ 1$ pkt 3 ustawy z 17 listopada 1964 r. Kodeks postępowania cywilnego ${ }^{49}$ (k.p.c.), która przewidywała, że skarga o stwierdzenie niezgodności z prawem prawomocnego orzeczenia sądu zostaje odrzucona bez wezwania strony do uzupełnienia braku, polegającego na niewskazaniu przepisu prawa, z którym zaskarżone orzeczenie jest niezgodne. Z jednej strony, TK uznał, że taka norma procesowa pozostaje w zgodzie z powyższym wzorcem konstytucyjnym, jednak z drugiej, stanowisko to nie może zostać wykorzystane w dalszych rozważaniach o konstrukcji podstawy kasacyjnej. Otóż niecałe trzy lata później TK wydał wyrok z 8 kwietnia 2014 roku $^{50}$, dotyczący normy procesowej z zakresu postępowania sądowoadministracyjnego, która stanowiła, że odrzuca się skargę kasacyjną, bez wezwania do usunięcia braku polegającego na niezamieszczeniu w niej wniosku o uchylenie lub zmianę orzeczenia wraz z oznaczeniem zakresu żądanego uchylenia lub zmiany (art. 180 w zw. z art. 178 i art. 176 p.p.s.a.). Została ona uznana za niezgodną z prawem powiązanym z zasadami proporcjonalności, dwuinstancyjności postępowania sądowego i ochrony zaufania obywateli do państwa i stanowionego przez nie prawa. Kluczowe w tym wyroku jest stanowisko TK, że rozstrzygnięcia we wspomnianej sprawie SK 49/08 nie można recypować w stosunku do warunków formalnych przewidzianych dla skargi kasacyjnej do NSA. Wynika to stąd, jak podkreślił TK, że skarga kasacyjna jest zwyczajnym środkiem zaskarżenia przysługującym od nieprawomocnego orzeczenia

48 SK 49/08, «OTK-A» 6/2011, poz. 55.

49 Wówczas Dz.U. Nr 43, poz. 296 ze zm., aktualnie tekst jedn. Dz.U. z 2014 r., poz. 101, ze zm.

50 SK 22/11, «OTK-A» 4/2014, poz. 37. 
WSA, który może doprowadzić do jego uchylenia bądź zmiany, natomiast skarga o stwierdzenie niezgodności z prawem prawomocnego orzeczenia sądu ma charakter nadzwyczajny, bowiem przysługuje od orzeczenia prawomocnego, a ponadto wyklucza jego uchylenie bądź zmianę, a pozwala jedynie na stwierdzenie, że jest ono sprzeczne z prawem. Dalej TK zauważył, że odrzucenie skargi kasacyjnej w zasadzie ma charakter definitywny, inaczej jest natomiast w razie odrzucenia skargi o stwierdzenie niezgodności z prawem prawomocnego orzeczenia - można ją wnieść ponownie po uzupełnieniu braków. Wreszcie TK przyznał, że nie można stawiać znaku równości pomiędzy niezamieszczeniem wniosku o uchylenie lub zmianę orzeczenia wraz z oznaczeniem zakresu uchylenia lub zmiany, a brakiem wskazania przepisu prawa.

Przytoczone różnice między skargą kasacyjną do NSA a uregulowaną w k.p.c. skargą o stwierdzenie niezgodności z prawem prawomocnego orzeczenia podważają zasadność wsparcia konstrukcji tego pierwszego środka zaskarżenia, stanowiskiem i argumentacją TK sformułowanymi w wyroku dotyczącym tego drugiego środka prawnego (SK 49/08). Dlatego należy zrezygnować z próby dowodzenia, że skoro warunek powołania przepisu prawnego w skardze o stwierdzenie niezgodności z prawem prawomocnego orzeczenia jest zgodny z powyższym wzorcem konstytucyjnym, to ten sam warunek, tyle że związany ze skargą kasacyjną do NSA, spełnia kryterium rzeczywistej możliwości powołania się na prawo UE.

Ocena pod względem kryterium rzeczywistej możliwości, warunku precyzyjnego wskazania przepisu prawnego w podstawie kasacyjnej i skutków jego niespełnienia nie powinna uwzględniać zasady proporcjonalności. Wynika to stąd, że zasada skuteczności w odniesieniu do przepisów procesowych kształtujących zakres rozpoznania sprawy przez sąd ogranicza się wyłącznie do kryterium rzeczywistej możliwości, pozostawiając na marginesie kwestię nadmiernego utrudnienia ${ }^{51}$. Dopiero bowiem w ramach kryterium nadmiernego utrudnienia analizuje się

${ }^{51}$ Kryterium rzeczywistej możliwości ma charakter dychotomiczny - albo istnieje, albo nie istnieje możliwość powołania się na prawo UE; podobnie jak będące jego „pierwowzorem” kryterium praktycznej niemożliwości zawarte w zasadzie skuteczności - realizacja prawa UE albo jest możliwa, albo nie jest, M. BовEK, op. cit., s. 316. 
proporcjonalność danego warunku (ograniczenia) formalnego w stosunku do jego celu na tle możliwości ochrony unijnego uprawnienia. Dla jasności wypada jednak przypomnieć, że zasada proporcjonalności nie zostaje całkowicie wyeliminowana z procesu stosowania kryterium rzeczywistej możliwości. Przejawia się ona w działaniu wspomnianej już proceduralnej reguły rozsądku, która zakłada, że po stwierdzeniu niezgodności przepisu procesowego z kryterium rzeczywistej możliwości należy ustalić, czy znajduje ono odpowiednio mocne i proporcjonalne oparcie w krajowych zasadach prawnych.

Warunek dokładnego wskazania przepisu prawa UE w podstawie kasacyjnej spełnia kryterium rzeczywistej możliwości, w rezultacie czego dla NSA nie powstaje obowiązek uwzględnienia z urzędu prawa UE, w razie niespełnienia tego warunku. Został on w sposób jasny sformułowany i ugruntowany w orzecznictwie NSA, stąd należy założyć, ze jest on znany profesjonalnym pełnomocnikom, którzy z należytą starannością powinni sporządzać skargi kasacyjne ${ }^{52}$. Zadanie sformułowania prawidłowej w tym aspekcie podstawy kasacyjnej nie powinno zresztą stanowić dla nich większego problemu, zważywszy na to, że dysponują fachową wiedzą i praktycznym doświadczeniem w sporządzaniu środków zaskarżenia, jak również wykazują się znajomością tekstów prawnych oraz akt sprawy, w tym uzasadnieniem wyroku WSA, które razem obrazują jej stan faktyczny i prawny ${ }^{53}$. Jeżeli zatem w przekonaniu profesjonalnego pełnomocnika WSA naruszył przepis prawa UE, to wystarczy, że

52 Konstrukcja podstaw kasacyjnych nie wprowadza nadmiernych rygorów formalnych, przez co spełnia standard wyznaczony konstytucyjną zasadą dwuinstancyjności postępowania sądowego, wymagający aby środek odwoławczy zapewniał skuteczne zaskarżenie i weryfikację rozstrzygnięcia sądu pierwszej instancji, W. PıĄTEK, op. cit., s. 117-118. Można dodać, że skoro rygory formalne budowy podstaw kasacyjnych nie są nadmierne, to tym bardziej nie są niemożliwe do spełnienia, co odnosi się m.in. do wskazania naruszonego przepisu prawa.

53 W literaturze zwrócono uwagę na to, że Trybunał Konstytucyjny zazwyczaj przyjmuje stanowisko, w myśl którego: „reprezentacja stron przez profesjonalistów może usprawiedliwiać przyjęcie dalej idących wymagań czynności postępowania, w tym również surowych wymogów procesowych", J. Pawliczak, M. WACH-Pawliczak, Konstytucyjne granice formalizmu postępowania cywilnego, "Monitor Prawniczy» 3/2012, s. 164. 
precyzyjnie wskaże ten przepis w prawidłowo skonstruowanej podstawie kasacyjnej, aby NSA zbadał, czy doszło do jego naruszenia.

Na tle warunku określenia przepisu prawnego w podstawie kasacyjnej ujawnił się szczególny problem. Dotyczy on sytuacji, w której w podstawie kasacyjnej wskazano na naruszenie przepisu prawa krajowego, natomiast pominięto przepis prawa UE, gdy oba przepisy regulują ten sam przedmiot. Czy w takim przypadku NSA powinien zbadać z urzędu również naruszenie przepisu prawa UE? Zdaniem Mariusza Barana odpowiedź jest twierdząca, jednak Autor jednocześnie zastrzega, że nie oznacza to wyjścia poza granice skargi kasacyjnej ${ }^{54}$. Uzasadniając swój pogląd zwraca uwagę na to, że ustalenia walidacyjne i interpretacyjne dotyczące przepisu prawa UE, przekładają się na stosowanie prawa krajowego, co prowadzi do konkluzji, że: „Naruszenie prawa unijnego bez względu na postać stanowi w gruncie rzeczy zawsze naruszenie prawa krajowego" ${ }^{55}$. Krótko mówiąc, Autor - jak sądzę - przyjmuje, że w naruszeniu przepisu prawa krajowego zawiera się mające wpływ na jego powstanie naruszenie przepisu prawa UE, gdy dotyczą one tego samego przedmiotu, a więc $\mathrm{w}$ ten sposób przepis unijny wchodzi razem z przepisem krajowym w zakres rozpoznania sprawy.

Przedstawione stanowisko uważam za trafne $\mathrm{z}$ kilku powodów. Główny cel skargi kasacyjnej polega na zweryfikowaniu przez NSA zgodności z prawem orzeczenia WSA ${ }^{56}$. Prawidłowe skonstruowanie podstawy kasacyjnej, wskazującej m.in. na naruszenie określonego przepisu prawa w drodze błędnej wykładni lub niewłaściwego zastosowania,

54 M. BARAn, op. cit., s. 431; podobnie K. Dobosz, M. Scheibe, Wplyw prawa Unii Europejskiej na działalność sądów administracyjnych - wybrane zagadnienia, «Zeszyty Naukowe Uniwersytetu Rzeszowskiego. Seria Prawnicza» 78/2013, s. 37.

55 M. BARAN, op. cit., s. 432. Stanowisko to zdaje się nawiązywać do obowiązującego w niektórych systemach procesowych rozróżnienia dwóch sytuacji: a) uzupełnienia przez sąd zarzutów przedstawionych w środku zaskarżenia, pozostających jednak w granicach sporu, b) uwzględnienia przez sąd z własnej inicjatywy naruszenia przepisu prawa, który nie został objęty zakresem sporu, gdyż nie wiąże się z żadnym zarzutem ze wskazanych w środku zaskarżenia, R.H. LAUwAARs, op. cit., s. 1166 i 1168. Rozgraniczenie w praktyce obu sytuacji bywa jednak skomplikowane, K. KowALIK-BAŃCZYK, op. cit., s. 20.

56 W. PiąTeK, op. cit., s. 119. 
stanowi warunek jego realizacji. Zbadanie przez NSA podstawy kasacyjnej, zgodne z celem skargi kasacyjnej, nie może ograniczać się tylko do oceny jej uzasadnienia, a więc stwierdzenia, że krytyka wykładni lub zastosowania przepisu prawa przez WSA jest trafna bądź chybiona. Rola NSA nie polega zatem tylko na zrecenzowaniu argumentów strony, skierowanych przeciwko orzeczeniu WSA. Spojrzenie takie wyklucza bowiem rzetelną i pełną weryfikację legalności orzeczenia ${ }^{57}$. Badanie powinno zatem obejmować także inne, niż zawarte w uzasadnieniu podstawy kasacyjnej przyczyny naruszenia przepisu prawnego. Błędna wykładnia lub niewłaściwe zastosowanie przepisu krajowego mogą w konsekwencji wynikać z ich niezgodności z przepisem prawa UE, co NSA powinien wziąć pod uwagę z własnej inicjatywy, aby przeprowadzić pełną ocenę podstawy kasacyjnej wówczas, gdy w niej lub w jej uzasadnieniu nie powołano przepisu unijnego. Postępując w ten sposób, NSA nie wychodzi poza granice skargi kasacyjnej, bowiem związanie dotyczy jej podstaw, a nie ich uzasadnienia, np. krytyki wykładni lub zastosowania prawa przez WSA. Jak trafnie uważa Bogusław Dauter: „Związanie NSA podstawami skargi kasacyjnej nie stoi na przeszkodzie, aby ten Sąd uwzględnił skargę w ramach powołanej podstawy, ale z odmiennym uzasadnieniem" ${ }^{58}$. Nie wchodzi w grę również uzupełnienie czy „dotworzenie” podstawy kasacyjnej, skoro naruszony przepis prawa krajowego został określony, a NSA sprawdza, czy źródło tego stanu rzeczy leży w naruszeniu prawa UE.

Biorąc pod uwagę, że NSA nie wykracza poza granice skargi kasacyjnej, gdy odwołuje się do przepisu unijnego niewskazanego w podstawie kasacyjnej ani w jej uzasadnieniu po to, aby zbadać naruszenie przepisu krajowego, to należy przyjąć, że nie zachodzi w tym przypadku „czyste” uwzględnienie przez sąd z urzędu prawa UE. Zarysowany sposób

57 W uchwale I OPS 10/09 NSA zaakcentował, że przepisy regulujące skargę kasacyjną należy tak interpretować, aby nie doszło do sytuacji, w której: „przepisy prawa pozwolą sądowi odwoławczemu utrzymać w mocy wyrok naruszający prawo, mimo stwierdzonego naruszenia”.

58 B. DAUter, op. cit., s. 543; wyrok NSA z 18 października 2007 r., II FSK 1230/06, «Legalis» nr 119043. 
odwołania się do prawa UE nie podlega zatem ocenie z punktu widzenia doktryny van der Weerd.

Ostatni już z przypadków analizowanych pod względem kryterium rzeczywistej możliwości ujawnia się wtedy, gdy NSA uchylił orzeczenie WSA i przekazał temu sądowi sprawę do ponownego rozpoznania (art. $185 \$ 1$ p.p.s.a.). Wówczas od nowego orzeczenia WSA przysługuje skarga kasacyjna, $\mathrm{z}$ tym że wykładnia prawa ustalona w tej sprawie przez NSA wiąże WSA, co dopełniane jest zakazem oparcia skargi kasacyjnej na podstawach sprzecznych z tą wykładnią (art. 190 p.p.s.a.). Oznacza to, że podstawa kasacyjna nie może zmierzać do wykazania, że taka powtórzona w nowym orzeczeniu WSA wykładnia przepisu prawa UE jest błędna. W rezultacie naruszenie przepisu unijnego nie powinno zostać objęte zakresem rozpoznania sprawy przez NSA. Ewidentnie zatem stronę pozbawia się rzeczywistej możliwości powołania prawa UE w środku zaskarżenia.

Zarysowana sytuacja ma szczególny charakter, bowiem przepis prawa UE już raz znalazł zastosowanie w sprawie rozpoznanej i rozstrzygniętej przez NSA. Zakaz skonstruowania podstawy kasacyjnej sprzecznej z wykładnią przepisu prawa UE ustaloną w orzeczeniu NSA służy zatem poszanowaniu rei iudicatae tego orzeczenia, w tym przyjętej w nim wykładni prawa, zapewnieniu, że nowe orzeczenie WSA będzie prawidłowe, a także zapobieżeniu ciągłemu zaskarżaniu rozstrzygnięć tak, aby sprawa nie „krążyła” wielokrotnie pomiędzy instancjami ${ }^{59}$. Podstawa kasacyjna opracowana wbrew temu zakazowi nie może być merytorycznie rozpoznana i prowadzi do oddalenia skargi kasacyjnej ${ }^{60}$.

Z uwagi na to, że przepis prawa UE już raz został objęty zakresem rozpoznania sprawy przez NSA, doktryna van der Weerd nie może skutkować obejściem zakazu sformułowania podstawy kasacyjnej sprzecznej z wykładnią NSA tylko dlatego, że strona się z nią nie zgadza, zaskarżając oparte na tej wykładni orzeczenie WSA. Przenosząc dotychczasowe spostrzeżenia na poziom proceduralnej reguły rozsądku należy uznać,

59 W. Sawczyn, Związanie kasacyjnym orzeczeniem Naczelnego Sądu Administracyjnego, Warszawa 2014, s. 53 i 136.

60 B. GruszczyńsKi, op. cit., s. 595. 
że znaczenie rei iudicatae orzeczenia NSA, a także potrzeba sprawnego przeprowadzenia i zakończenia postępowania przeważają w tym przypadku nad osiągnięciem efektywności prawa UE i dlatego omawiany zakaz (art. 190 zd. drugie p.p.s.a), chociaż nie czyni zadość kryterium rzeczywistej możliwości, to jest usprawiedliwiony powołanymi wartościami prawa krajowego. Dla NSA nie powstaje zatem obowiązek uwzględnienia z urzędu przepisu prawa UE.

Odwrotne stanowisko należałoby z kolei przyjąć wtedy, gdy o błędnej wykładni przepisu prawa UE ustalonej przez NSA świadczy nie sama argumentacja strony, lecz wyrok prejudycjalny TSUE. W grę wchodzą wyroki TSUE wydane aż do momentu rozpoznania ponownej skargi kasacyjnej, bowiem działają one zasadniczo ze skutkiem ex-tunc ${ }^{61}$, wiążą erga omnes ${ }^{62}$, a dodatkowo zasada lojalnej współpracy ${ }^{63}$ wymaga od krajowej judykatury, aby wydawane rozstrzygnięcia nie pozostawały w sprzeczności z dorobkiem orzeczniczym TSUE ${ }^{64}$, co łącznie ma przekładać się na efektywną i jednolitą wykładnię prawa UE w krajowych systemach prawnych ${ }^{65}$. Uwzględnienie w takim wypadku przez NSA $\mathrm{z}$ urzędu przepisu prawa UE, wbrew zakazowi ustanowionemu $\mathrm{w}$ art. 190 zd. drugie p.p.s.a., zmierza więc do wydania rozstrzygnięcia trafnego z perspektywy prawa UE, dostosowanego do orzecznictwa TSUE $\mathrm{i}$ „zastępującego" 66 wcześniejsze, nieprawidłowe w tym aspekcie roz-

61 C. Mıк, Europejskie prawo wspólnotowe. Zagadnienia teorii i praktyki, I, Warszawa 2000, s. 712 .

62 K. Lenaerts, op. cit., s. 1642; A. Tizzano, [w:] R. Adam, M. Safjan, A. Tizzano, Zarys prawa Unii Europejskiej, Warszawa 2014, s. 348.

63 W myśl art. 4 ust 3 akapit drugi Traktatu o Unii Europejskiej (wersja skonsolidowana Dz.UE. C 202 z 7.6.2016 r.): „Państwa Członkowskie podejmują wszelkie środki ogólne lub szczególne właściwe dla zapewnienia wykonania zobowiązań wynikających z Traktatów lub aktów instytucji Unii”.

64 J. Temple Lang, Developments, Issues, and New Remedies - The Duties of National Authorities and Courts Under Article 10 of the EC Treaty, «Fordham International Law Journal» 6/2004, s. 1911.

${ }_{65}$ Wyrok TSUE z 12 czerwca 2008 r. w sprawie Skatteverket przeciwko Gourmet Classic Ltd., C-458/06, pkt 23, «Zb. Orz.» 2008, s. I-04207.

66 Nowe orzeczenie NSA oczywiście nie uchyla wcześniejszego orzeczenia, lecz w obrocie wiążąca będzie wykładnia prawa UE przedstawiona w nowym orzeczeniu. 
strzygnięcie NSA. Korzystając z proceduralnej reguły rozsądku należy stwierdzić, że zapewnienie zgodności orzeczenia NSA z wyrokiem prejudycjalnym TSUE, a tym samym z prawem UE, uzasadnia przełamanie błędnej wykładni prawa UE ustalonej w poprzednim, prawomocnym orzeczeniu NSA oraz ponowne rozpoznanie i rozstrzygnięcie sprawy oparte na wyroku TSUE ${ }^{67}$. Konkludując, jeżeli w orzeczeniu NSA uchylającym orzeczenie WSA i przekazującym sprawę do ponownego rozpoznania została przyjęta wykładnia przepisu prawa UE niezgodna z wykładnią ustanowioną wyrokiem prejudycjalnym TSUE, to NSA rozpoznając ponowną skargę kasacyjną wniesioną od nowego orzeczenia WSA, ma obowiązek uwzględnienia $z$ urzędu przepisu prawa UE, z pominięciem zakazu, o którym mowa w art. 190 zd. drugie p.p.s.a.

\section{Podsumowanie}

Zasada skuteczności może spowodować, że dla sądu krajowego w szczególnej sytuacji powstanie obowiązek uwzględnienia z urzędu prawa UE. Stanie się tak wtedy, gdy krajowa norma procesowa nie zapewni jednostce rzeczywistej możliwości powołania się w postępowaniu na unijny przepis. Po stwierdzeniu naruszenia kryterium rzeczywistej możliwości należy jeszcze zrobić użytek z proceduralnej reguły rozsądku oceniając, czy normę procesową dostatecznie mocno wspierają wartości zawarte w zasadach prawa krajowego. Jeżeli zbiór określonych wartości

67 Na marginesie warto odnotować, że TSUE opowiedział się za dopuszczalnością wzruszenia prawomocnego orzeczenia sądu krajowego w celu jego dostosowania do wyroku prejudycjalnego TSUE. W wyroku z 10 lipca 2014 r. w sprawie Impresa Pizzarotti \& C. Spa przeciwko Comune di Bari i in., C-213/13, «Legalis» nr 981943, Trybunał stwierdził, że: „O ile obowiązujące krajowe zasady proceduralne zezwalają na to, sąd krajowy, taki jak sąd odsyłający, który rozstrzygał w ostatniej instancji, bez uprzedniego zwrócenia się do Trybunału Sprawiedliwości Unii Europejskiej o wydanie orzeczenia w trybie prejudycjalnym na podstawie art. 267 TFUE, powinien uzupełnić wydane przez ten sąd orzeczenie posiadające powagę rzeczy osądzonej, które prowadziło do sytuacji niezgodnej z przepisami Unii dotyczącymi zamówień publicznych na roboty budowlane, lub dokonać zmiany tego orzeczenia, uwzględniając wykładnię tych przepisów dokonaną następnie przez wskazany Trybunał”. 
przeważy nad efektywnością prawa UE, to nie powstanie obowiązek uwzględnienia z urzędu przepisu unijnego. Natomiast odwrotny wynik ważenia obowiązek ten zaktualizuje. Analiza wybranych regulacji procesowych dotyczących konstrukcji podstaw kasacyjnych pod względem zasady skuteczności pokazała, w jakich sytuacjach NSA nie powinien uwzględniać z urzędu prawa UE, a w jakich powinien.

W przypadku, gdy we wniesionej po raz pierwszy w sprawie skardze kasacyjnej w ogóle nie została sformułowała podstawa kasacyjna odnosząca się do prawa UE, to nie powstaje dla NSA obowiązek uwzględnienia z urzędu przepisu unijnego. Warunki konstrukcyjne podstawy kasacyjnej spełniają bowiem kryterium rzeczywistej możliwości. Ponadto brak podstawy kasacyjnej można tu traktować jako przejaw bierności strony (doktryna Asturcom), której negatywne konsekwencje obciążają tylko stronę, a NSA nie może ich usunąć.

Podobnie, skoro warunek precyzyjnego wskazania przepisu unijnego w podstawie kasacyjnej jest zgodny z kryterium rzeczywistej możliwości, to NSA nie ma obowiązku uwzględnienia z urzędu tego przepisu, jeśli omawiany warunek nie został spełniony. Należy bowiem pamiętać, że opracowaniem i uzasadnieniem podstaw kasacyjnych zajmuje się profesjonalny pełnomocnik. Istotne jest przy tym, aby rozróżnić dwie sytuacje: a) zarzutu „samodzielnego” naruszenia przepisu unijnego, tj. bez ścisłego związku z naruszeniem przepisu krajowego, do czego odnosi się powyższe twierdzenie, b) zarzutu naruszenia przepisu unijnego, stanowiącego przyczynę naruszenia przepisu krajowego, gdy obie regulacje merytorycznie odnoszą się do tego samego zakresu przedmiotowego, a podstawa kasacyjna obejmuje tylko przepis krajowy. W tej drugiej sytuacji NSA powinien zbadać naruszenie przepisu krajowego w świetle prawa UE, jednak nie mamy tu do czynienia z czystym działaniem sądu z urzędu, tylko z rozpoznaniem podstawy kasacyjnej w jej granicach.

Obowiązek uwzględnienia przez NSA z urzędu prawa UE może z kolei powstać w razie wniesienia kolejnej skargi kasacyjnej, gdy NSA na podstawie art. $185 \$ 1$ p.p.s.a. uchylił orzeczenie WSA i przekazał sprawę do ponownego rozpoznania. Wejdzie on w grę pod warunkiem, że ustalona w orzeczeniu NSA wykładnia prawa UE, okaże się niezgodna z wyrokiem prejudycjalnym TSUE, bowiem art. 190 zd. drugie p.p.s.a. zakazując skonstruowania podstawy kasacyjnej sprzecznej z wykładnią NSA, zamyka stronie rzeczywistą 
możliwość powołania się na prawo UE. Uzasadnienie dla powstania omawianego obowiązku bierze się z wymogu rozstrzygnięcia sprawy przez NSA w zgodzie $\mathrm{z}$ wyrokiem prejudycjalnym TSUE, co przyczyni się do urzeczywistnienia efektywności i jednolitości stosowania prawa UE.

W przedstawionej sytuacji swoje działanie zaznaczyła więc proceduralna reguła rozsądku. $Z$ dotychczasowych rozważań płynie jednak wniosek, że nie w każdym przypadku było konieczne skorzystanie z niej. Nie ma takiej potrzeby w sytuacji zupełnego braku podstawy kasacyjnej oraz niewskazanie w niej przepisu prawa UE. Kryterium rzeczywistej możliwości nie zostało tu bowiem naruszone przez krajową regulację procesową, dlatego też przejście do jej rozpatrzenia w kontekście zasad prawa krajowego i zestawienie ich z efektywnością prawa UE, nie byłoby użyteczne dla stwierdzenia, czy dla NSA (nie)powstał obowiązek uwzględnienia $\mathrm{z}$ urzędu przepisu unijnego.

Warto podkreślić, że również doktryna Asturcom nie posiada uniwersalnego zastosowania. Trudno zakwalifikować niewskazanie przepisu prawa UE w podstawie kasacyjnej jako przypadku zupełnej bierności strony, mamy tu raczej do czynienia $\mathrm{z}$ niedbałością. Tym bardziej nie może być mowy o zupełnej bierności strony, gdy zacznie działać zakaz sformułowania podstawy kasacyjnej sprzecznej z wykładnią ustaloną przez NSA (art. 190 zd. drugie p.p.s.a.). Doktryna Asturcom okazała się natomiast przydatna, gdy we wniesionej po raz pierwszy skardze kasacyjnej zupełnie pominięto podstawę kasacyjną związaną z prawem UE, co rzeczywiście można uznać za przejaw bierności strony.

W niniejszym artykule poruszono tylko niektóre zagadnienia dotyczące obowiązku uwzględnienia przez sąd z urzędu prawa UE. Warto zatem, aby doktryna i judykatura podejmowały dalsze rozważania, zmierzające do analizy skargi kasacyjnej do NSA pod kątem doktryn van der Weerd i Asturcom. Uważam przy tym, że NSA powinien przede wszystkim samodzielnie czynić użytek z wymienionych narzędzi, tj. bez współpracy z TSUE w drodze pytania prejudycjalnego. Są one bowiem używane odnośnie do prawa krajowego, a interpretowanie i stosowanie ich należy do kompetencji NSA, nie zaś do TSUE. Korzystanie z pytania prejudycjalnego do Trybunału w kwestiach związanych z obowiązkiem uwzględnienia z urzędu prawa UE powinno być natomiast zastrzeżone dla 
trudnych przypadków, wykraczających poza granice jednostkowej sprawy, gdzie źródłem wątpliwości jest treść prawa UE, np. znaczenie kryterium rzeczywistej możliwości, do wykładni którego właściwy jest Trybunał.

\section{ZASADA SKUTECZNOŚCI JAKO PODSTAWA OBOWIĄZKU UWZGLĘDNIENIA PRZEZ NSA Z URZĘDU PRAWA UE}

\section{Streszczenie}

Celem artykułu było ustalenie, czy dla NSA rozpoznającego sprawę w granicach skargi kasacyjnej, może w określonych przypadkach powstać obowiązek uwzględnienia z urzędu prawa UE, na podstawie zasady skuteczności, która wynika z prawa UE. Artykuł obejmuje trzy części. W pierwszej scharakteryzowano podstawy kasacyjne i zasadę związania NSA granicami skargi kasacyjnej. Druga dotyczy treści zasady skuteczności i sposobu korzystania z niej w odniesieniu do krajowych reguł procesowych. W ostatniej części zbadano trzy warunki konstrukcji podstawy kasacyjnej pod kątem zasady skuteczności. Wnioski są następujące. $Z$ jednej strony, obowiązek uwzględnienia przez NSA z urzędu prawa UE nie powstaje wtedy, gdy w skardze kasacyjnej w ogóle nie sformułowano podstawy kasacyjnej dotyczącej naruszenia prawa UE, jak również gdy sformułowano ją nieprawidłowo, bez wskazania konkretnego przepisu prawa UE. Z drugiej strony, obowiązek ten wchodzi w grę przy ponownej skardze kasacyjnej wniesionej w tej samej sprawie gdy okaże się, że wykładnia prawa UE ustalona we wcześniejszym orzeczeniu NSA, jest niezgodna z wyrokiem prejudycjalnym TSUE.

The Principle of Effectiveness as the Grounds for the Polish Supreme Administrative Court's Obligation to Apply EU LaW of Its Own Motion

\section{Summary}

The aim of this article was to determine whether in certain cassation cases heard by the Polish Supreme Administrative Count (SAC) there 
may be an obligation resting on this court to take EU law into consideration of its own motion, on the grounds of the EU principle of effectiveness. The article is divided into three parts. The first part describes the grounds for cassation and the bounds to the SAC's adjudication. The second part presents the principle of effectiveness and the way in which it is applied with respect to Poland's domestic procedural regulations. The last part examines three conditions for the construction of grounds for complaint from the point of view of the principle of effectiveness. The following conclusions may be drawn from my study. On the one hand, there is no obligation for the SAC to apply EU law of its own motion if no grounds for cassation have been drawn up on the basis of EU law at all, or if they have been formulated incorrectly, without a specification which provision of EU law has been breached. But on the other hand the SAC is obliged to take EU law into consideration in the event of a renewed complaint should it turn out that its original verdict was incompatible with the preliminary ruling issued by the EU Court of Justice.

Słowa kluczowe: Naczelny Sąd Administracyjny, skarga kasacyjna, podstawy kasacyjne, granice skargi kasacyjnej, prawo UE, zasada skuteczności, stosowanie przez sąd prawa UE z urzędu .

Keywords: Supreme Administrative Court; cassation complaint; grounds for complaint; bounds to a cassation complaint; EU law; principle of effectiveness; a court's application of EU law of its own motion.

\section{Literatura}

Adam R., Safjan M., Tizzano A., Zarys prawa Unii Europejskiej, Warszawa 2014

ADAmiak B., Skarga i skarga kasacyjna w postępowaniu sądowoadministracyjnym, Komentarz, Warszawa 2014

BARAn M., Stosowanie z urzędu prawa Unii Europejskiej przez sądy krajowe, Warszawa 2014

Bielska-Brodziak A., Zarzut „błędnej wykładni”, «Ruch Prawniczy Ekonomiczny i Socjologiczny» $1 / 2006$

Bовек M., Why there is no principle of "procedural autonomy" of the member states, [w:] The European Court of Justice and the autonomy of the member states, red. H.W. Micklitz, B. De Witte, Cambridge-Antwerp-Portland 2012 
Dauter B., Metodyka pracy sędziego sq̨du administracyjnego, Warszawa 2012 Dobosz K., Scheibe M., Wpływ prawa Unii Europejskiej na działalność sądów administracyjnych - wybrane zagadnienia, «Zeszyty Naukowe Uniwersytetu Rzeszowskiego. Seria Prawnicza»78/2013

Eliantolio M., Europeanisation of Administrative Justice?, Groningen 2009

Engström J., National Courts' Obligation to Apply Community Law Ex Officio - The Court Showing new Respect for Party Autonomy and National Procedural Autonomy?, «Review of European Administrative Law» 1/2008

Engström J., The Principle of Effective Judicial Protection after Lisbon Treaty, «Review of European Administrative Law» 2/2011

KaNiA M., Zwyczajne środki zaskarżenia w postępowaniu przed sądami administracyjnymi, Warszawa 2009

Kmiecia K Z., Podstawy skargi kasacyjnej do Naczelnego Sądu Administracyjnego, «PiP» 60.1/2005

KMieciak Z., Postepowanie administracyjne i sadowoadministracyjne a prawo europejskie, Warszawa 2010

KNysiak-Molczyк H., Skarga i skarga kasacyjna w postępowaniu sądowoadministracyjnym. Komentarz. Orzecznictwo, Warszawa 2014

KowALIK-BAŃCZY к K., Uwzględnianie przez sąd $z$ urzędu zarzutów opartych na prawie wspólnotowym, «Europejski Przegląd Sądowy» 12/2007

LauwaArs R.H., The Application of European Law by National Courts Ex Officio, «Fordham International Law Journal» 5/2005

LenAerts K., The Rule of Law and the Coherence of the Judicial System of the European Union, «Common Market Law Review» 6/2007.

Lenaerts K., Maselis I., Gutman K., EU Procedural Law, Oxford University Press 2015

ŁUKASIK K., Konstytucyjne prawo do sq̨du „każdego” a przymus adwokacko-radcowski $w$ sprawie skargi kasacyjnej w postępowaniu przed Sądem Najwyższym, «Annales Univeristatis Mariae Curie-Skłodowska. Sectio G» 2/2013

Majkowska S., Rola sędziów w procesie integrowania prawa wspólnotowego z wewnętrznym porzadkiem prawnym, [w:] Wymiar sprawiedliwości w Unii Europejskiej, red. C. Miк, Toruń 2001

MAтcZAк M., 'Summa Iniuria'. O błędzie formalizmu w stosowaniu prawa, Warszawa 2007

Мıк C., Europejskie prawo wspólnotowe. Zagadnienia teorii i praktyki, I, Warszawa 2000

Pawliczak J., Wach-Pawliczak M., Konstytucyjne granice formalizmu postępowania cywilnego, «Monitor Prawniczy» 3/2012 
Piątek W., Podstawy skargi kasacyjnej w postępowaniu sądowoadministracyjnym, Warszawa 2011

Postulski W., Jednolite i efektywne stosowanie prawa wspólnotowego przed sądami państw członkowskich, «Przegląd Sądowy» 6/2002

PóŁTORAK N., Efektywność prawa Unii Europejskiej a polska procedura administracyjna i sądowoadministracyjna, "Zeszyty Naukowe Sądownictwa Administracyjnego» 3/2014

PóŁtorak N., Ochrona uprawnień wynikających z prawa Unii Europejskiej $w$ postępowaniach krajowych, Warszawa 2010

Prawo o postępowaniu przed sądami administracyjnymi. Komentarz, DAUTER B., Gruszczyński B., Kabat A., NiezgódKa-Medek M., Warszawa 2011.

Prechal S., Widdershoven R., Redefining the Relationship between „Rewe-effectiveness" and Effective Judicial Protection, "Review of European Administrative Law» 2/2011

RzĄSA G., Podstawy skargi kasacyjnej w postępowaniu sądowoadministracyjnym, «PiP» 63.8/2008

SawCzyn W., Związanie kasacyjnym orzeczeniem Naczelnego Sądu Administracyjnego, Warszawa 2014

Schebesta H., Does the National Court Know European Law? A Note on Ex Officio Application after Asturcom, «European Review of Private Law» 4/2010 System prawa administracyjnego, X: Sadowa kontrola administracji, red. R. Hauser, Z. Niewiadomski, A. Wróbel, Warszawa 2014

TARno J.P., Ewolucja orzecznictwa Naczelnego Sadu Administracyjnego w zakresie podstaw skargi kasacyjnej i zażalenia, «Zeszyty Naukowe Sądownictwa Administracyjnego» 5-6/2010

TArno J.P., Odrzucenie skargi kasacyjnej, «Przegląd Podatkowy» 6/2005

Temple Lang J., Developments, Issues, and New Remedies - The Duties of National Authorities and Courts Under Article 10 of the EC Treaty, «Fordham International Law Journal» 6/2004

Temple Lang J., The Principle of Loyal Cooperation and the Role of the National Judge in Community, Union and EEA Law, «ERA Forum» 7/2006

WiĄCEK M., Skarga kasacyjna do Naczelnego Sadu Administracyjnego (w świetle orzecznictwa), «Państwo i Prawo» 66.3/2011

Wróbel A., Sądy administracyjne jako sądy Unii Europejskiej, «Zeszyty Naukowe Sądownictwa Administracyjnego» 5-6/ 2010

Van Cleynenbreugel P., Judge-Made Standards of National Procedure in Post-Lisbon Constitutional Framework, «European Law Review» 1/2012. 